\title{
INTENSIVE BEEF AND SHEEP PRODUCTION
}

\section{J. P. JOYCE}

Ruakura Agricultural Research Centre, Hamilton

\section{Summary}

An experiment is described in which the comparative productivity per acre has been measured using three classes of stockbreeding ewes, wethers and dairy beef cattle. Results have been expressed in terms of pasture production, feed Intakes, feed conversion efficiency, and output of meat and wool Per acre. These results have been discussed with particular reference to the potential production levels of various classes of livestock on a per-acre basis.

\section{INTRODUCTION}

To INCREASE animal productivity per acre on sheep farms in New Zealand within present limits of pasture production, the most practical method, other than by improving the genetic merit of present livestock, is either to increase stocking rates or to change the class of livestock carried. While there exists a relatively large volume of published results on the effects of increased stocking rate, comparatively little is known on the relative per-acre production of either dry sheep or young beef cattle compared with breeding ewes.

Walker (1959), in earlier trials at Ruakura, showed that the partial or complete substitution of either breeding cows or fattening cattle for breeding ewes had little or no effect on meat production per acre but of necessity lowered wool production per acre. With the relatively modern concept of using cattle of dairy origin for beef production during their phase of fastest growth and possibly greatest feed conversion efficiency, this relationship shown earlier by Walker may no longer be valid.

An experiment at Ruakura, described in this paper, examined the comparative productivity per acre of export lamb, dry sheep and dairy beef cattle systems at stocking rates designed to be at similar grazing intensities for all three classes of stock.

\section{EXPERIMENTAL}

The basic experimental design is shown in Table 1. The three systems of farming employed were: 
INTENSIVE BEEF AND SHEEP PRODUCTION

TABLE 1: STOCKING RATES v. CLASS OF STOCK

\begin{tabular}{|c|c|c|c|}
\hline \multirow{2}{*}{$\begin{array}{l}\text { Class of Stock } \\
\text { Breeding ewes ( } 5 \text { and } 6 \text { yr Romney) } \\
\text { Dairy beef steers: }\end{array}$} & \multicolumn{3}{|c|}{$\begin{array}{l}\text { Stocking Rate } \\
\text { (animals/acre) }\end{array}$} \\
\hline & 8 & 10 & 12 \\
\hline Winter & 1.5 & 2.0 & 2.5 \\
\hline Spring-autumn & 3.0 & 4.0 & 5.0 \\
\hline $\begin{array}{l}\text { Wether lambs (Romney and Romney- } \\
\text { cross) }\end{array}$ & 11 & 14 & 17 \\
\hline
\end{tabular}

1. Breeding ewes: Five- and six-year-old Romney ewes mated to Southdown rams for export lamb and wool production, stock at rates of eight, ten and twelve per acre.

2. Dairy Beef: Friesian steer calves of eight to ten weeks of age, weighing 150 to $200 \mathrm{lb}$, were brought on in September-October. These were then slaughtered at 15 to 18 months of age, prior to their second wintering period, at liveweights of 800 to $900 \mathrm{lb}$. The stocking rates employed were one and a half, two and two and a half per acre, although these rates doubled during the springautumn period when both calves and yearlings were on each area.

3. Wethers: Store Romney or Romney-cross wether lambs were brought on in December and stocked at rates of 11,14 and 17 per acre. These were carried through one winter and slaughtered the following spring, before the new intake of wether lambs arrive.

All groups of stock were rotationally grazed around their areas except for the three ewe groups which were setstocked over the lambing period. The trial commenced in 1967 and is now completing its fourth and final year. The highest stocking rate in each class of stock was not necessarily self-contained in the amount of pasture conserved for winter feeding. If necessary, extra feed, in the form of hay or silage, not conserved on the area, was brought in to prevent animals from losing liveweight at a greater rate than those groups which were self-sufficient in the amount of feed conserved from their areas,

Measurements were made of pasture production and apparent pasture utilization using the "Australian dif-, ference" method as outlined by Lynch (1960). Individual animal feed intakes were measured using the chromic oxide method of measuring faecal dry matter output and the in vitro method of determining pasture digestibility. 


\section{RESULTS}

\section{Pasture Production}

In Table 2 are shown the levels of pasture production recorded during the last two years of the experiment. During 1967-8, the first year of the trial, there appeared to be no pattern in the levels of pasture production. During this last season there appear to have been slight differences in the amounts of pasture grown on the nine areas. The cattle areas produced $8.1 \%$ and $22.5 \%$ more dry matter than the ewe and wether areas, respectively, and the highest stocked areas averaged 5\% less pasture than the lightest stocked areas. The most marked changes observed in botanical composition of the pastures were the replacement of ryegrasses by annual grasses on the 12 ewes per acre paddocks and the large proportion of Yorkshire fog on all the lighter stocked cattle, ewe and wether treatment areas.

TABLE 2: PASTURE PRODUCTION

\begin{tabular}{|c|c|c|}
\hline & $\begin{array}{c}\text { Ib } D \\
1967-8\end{array}$ & $\begin{array}{l}\text { year } \\
1968.9\end{array}$ \\
\hline \multicolumn{3}{|c|}{ Cattle per acre: } \\
\hline $1 \frac{1}{2}$ & 11,050 & 13,830 \\
\hline 2 & 9,650 & 13,540 \\
\hline $2 \frac{1}{2}$ & 10,990 & 12,710 \\
\hline \multicolumn{3}{|c|}{ Ewes per acre: } \\
\hline 8 & 10,630 & 12,020 \\
\hline 10 & 12,220 & 12,970 \\
\hline 12 & 10,840 & 12,090 \\
\hline \multicolumn{3}{|c|}{ Wethers per acre: } \\
\hline 11 & - & 11,310 \\
\hline 14 & - & 10,870 \\
\hline 17 & - & 10,540 \\
\hline
\end{tabular}

\section{Comparative Productivity}

'The three-year average production per acre results, in terms of meat and wool, are given in Table 3. Cattle systems produced approximately twice the weight of meat per acre obtained under a sheep system. The net meat production has been calculated as the weight of carcass meat slaughtered at the end of each year less the weight of carcass brought on to each area as either weaner steers or weaned lambs. The wether system, for which only one year's results are available, tended to produce slightly 
INTENSSIVEE BEEF AND SHEEP PRODUCTION

TABLE 3: COMPARATIVE PRODUCTIVITY PER ACRE (3-year average)

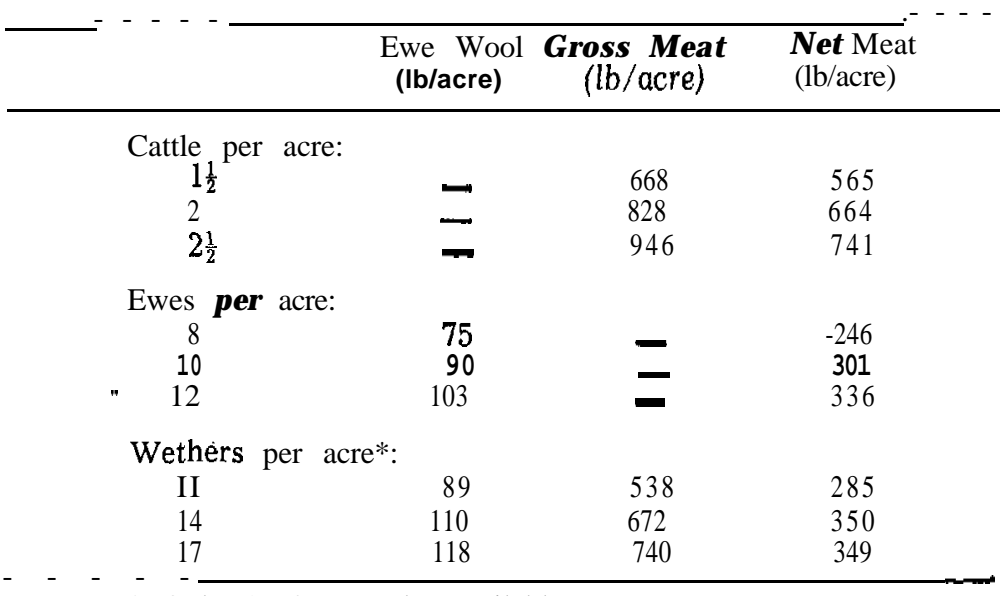

* Only 1968-9 results available.

more meat and wool per acre than did the export lamb system. In general, more meat and wool were produced per acre at higher stocking rates than at lower stocking rates. However, the highest stocking rate of each system of farming was not necessarily self-contained in terms of feed supply in all years. While wool weight per acre increased with increasing stocking rate, wool weight per ewe declined and wool quality was drastically reduced; this difference in wool quality was not reflected in a drop in auction sale value per $\mathrm{lb}$ weight. Similarly, carcass weights and fat cover of cattle carcasses decreased with increasing stocking rate.

\section{Conversion of Pasture Dry Matter}

The amount of meat produced per 1,000 lb DM grown per acre (Table 4) was again greater for cattle systems of farming than for either of the two sheep farming systems. Similarly, the feed conversion efficiency of all classes of stock increased with increasing stocking rate.

In Fig. 1 are shown the differences between pasture growth and feed consumption for the middle stocking rate of two of the farming systems on a monthly basis. At ten ewes per acre, a considerable pasture surplus occurred in the October-January period 1968-9. The pattern in the preceding and succeeding season showed a greater pasture 
10 EWES/ACRE
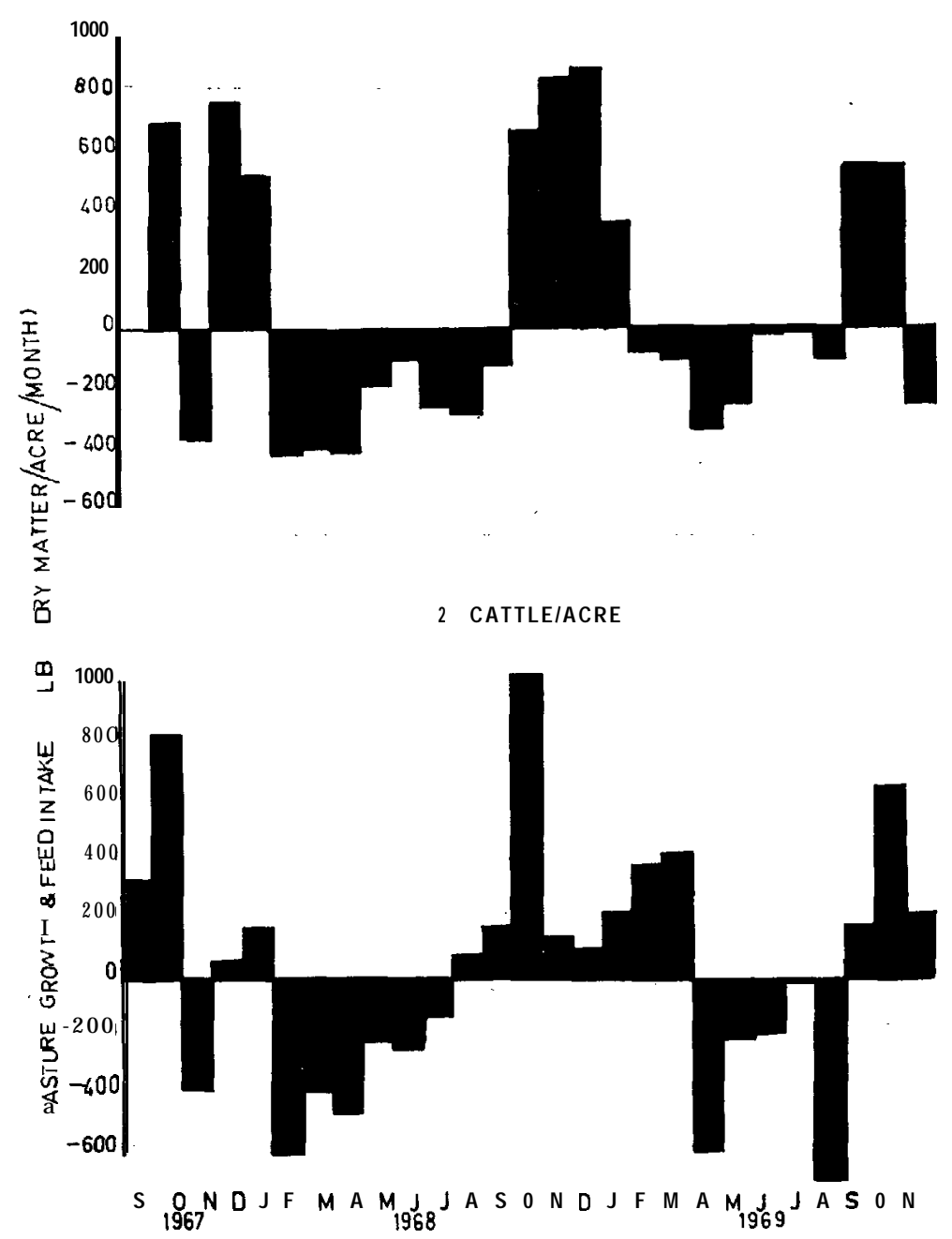

FIG. 1: Feed surplus and deficit, 10 ewes per acre and 2 cattle per acre.

consumption than production in the November period when ewe and lamb requirements were at their highest point. The pasture growth surplus of the two cattle per acre tended to extend over a longer period, normally starting in the August-September period and continuing until January- 
INTENSIVE BEEF AND SHEEP PRODUCTION

TABLE 4: CONVERSION OF 'PASTURE DRY MATTER (3-year average)

\begin{tabular}{|c|c|c|}
\hline & $\begin{array}{c}\text { lb Meat/ } \\
1,000 \mathrm{lb} D M\end{array}$ & 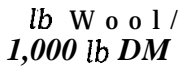 \\
\hline \multicolumn{3}{|c|}{ Cattle per acre: } \\
\hline $1 \frac{1}{2}$ & 45.4 & - \\
\hline $2^{2}$ & 57.2 & - \\
\hline $2 \frac{1}{2}$ & 62.5 & $m$ \\
\hline \multicolumn{3}{|c|}{ Ewes per acre: } \\
\hline 8 & 21.7 & 6.6 \\
\hline 10 & 23.9 & 7.1 \\
\hline 12 & 29.3 & 9.0 \\
\hline \multicolumn{3}{|c|}{ Wethers per acre*: } \\
\hline 11 & 25.2 & 7.9 \\
\hline 14 & 32.2 & 10.2 \\
\hline 17 & 33.1 & 11.2 \\
\hline
\end{tabular}

* 1968-9 season only.

March. In the wether system of farming, a large feed surplus existed except in the period March to August. This large surplus, conserved as hay and unused at the end of the season, was a feature of all the wether treatments.

\section{FEED INTAKE}

The feed intakes measured in this experiment are shown in Table 5 together with the calculated ewe equivalent values for the various classes of stock, assuming that the standard ewe equivalent is a Romney ewe producing a single lamb and consuming 1,230 lb DM/year. The feed intake or requirement of $7,320 \mathrm{lb}$ of DM for a Friesian steer to reach $900 \mathrm{lb}$ at 15 months of age is somewhat arbitrary since the ewe equivalence is to some extent controlled by the rate of growth of the animal. This is illustrated in Fig. 2. In the 1967-8 season, cattle, stocked at a rate of 1.5 /acre, reached $820 \mathrm{lb}$ liveweight by mid-January and in doing so required 6,700 $\mathrm{lb}$ DM (E.E. 5.4) ; in the next season, 1968-9, owing to the better feed conditions in the winter period, they reached a similar weight $(816 \mathrm{lb})$. by midNovember, and in doing so required only 5,910 lb. DM (E.E: 4.8) -i.e., $12 \%$ less feed. 


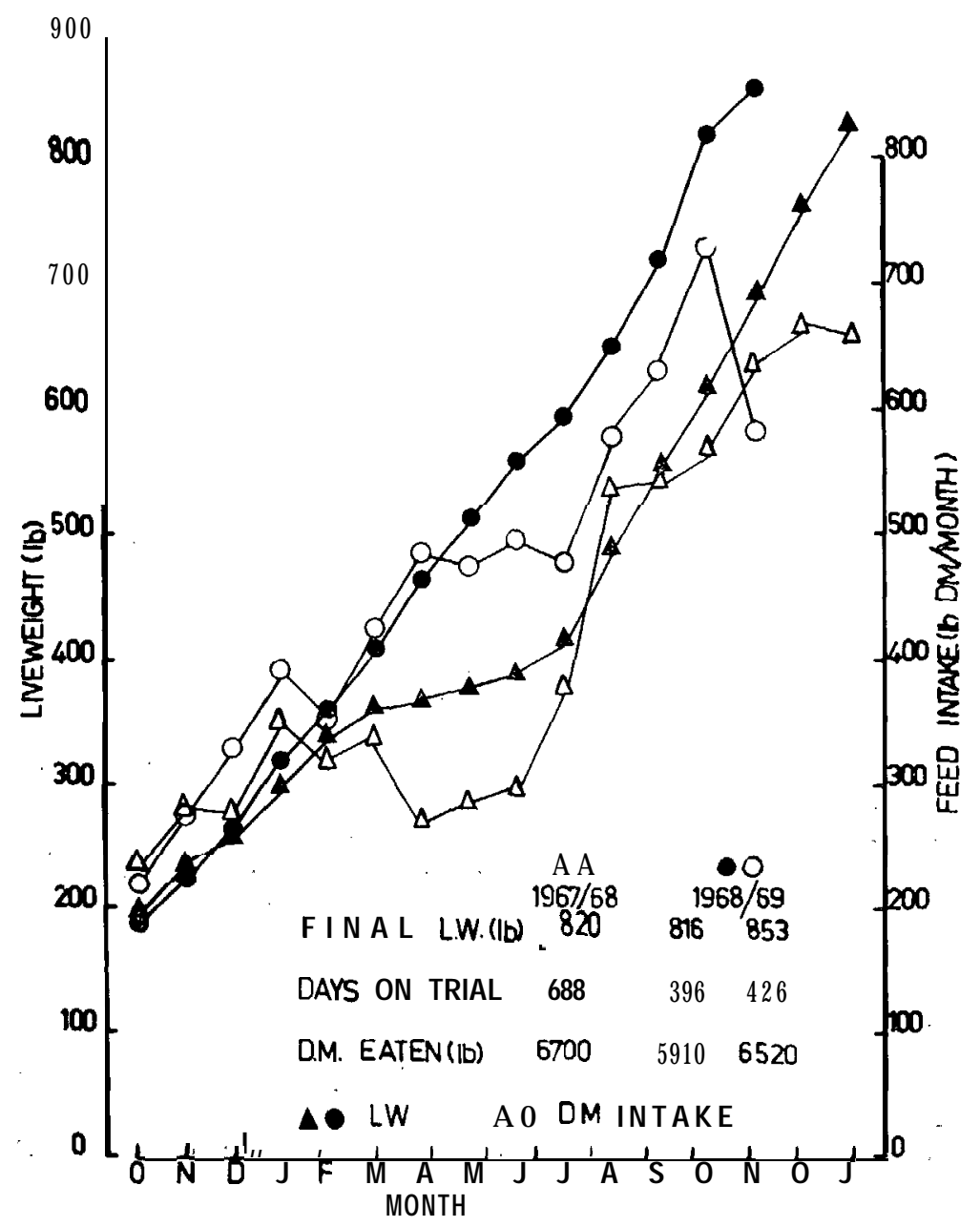

Fig. 2: Feed intake and liveweight gain, 1.5 cattle per acre.

\section{DISCUSSION}

The young dairy beef. animal, slaughtered at 800 to $1,000 \mathrm{lb}$ liveweight prior to its second wintering period, produces considerably more meat per acre than the breeding ewe. In earlier trials, Walker (1959) was unable to demonstrate any superiority of the:breeding beef cow over

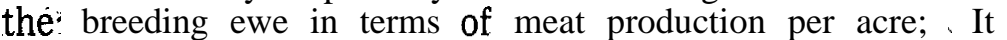
is thus apparent that the high overhead feed cost of meet- 
INTENSIVE BEEF AND SHEEP PRODUCTION

TABLE 5: FEED INTAKES

\begin{tabular}{ccc}
\hline & lb DM/year & E.E. \\
\hline Romney ewe: & & \\
Single lamb & 1,230 & 1.0 \\
Twin lamb & 1,570 & 1.3 \\
$90 \mathrm{lb}$ & 610 & $\mathbf{0 . 5}$ \\
Romney wether lamb: & & \\
$50 \mathrm{lb} 100 \mathrm{lb}$ & 685 & $\mathbf{0 . 5 5}$ \\
(Jan.) (Nov.) & 750 & $\mathbf{0 . 6}$ \\
Friesian steer: & & \\
170 lb 900 lb & 7,320 & $\mathbf{6 . 0}$ \\
(2 mon.) (15 mon.) & & \\
\hline
\end{tabular}

ing the maintenance requirement of the ewe is penalizing the lamb meat system of farming and that the benefit of wool production is not compensating for the lower meat production. Two questions require answering: first, what is the potential production per acre under a dairy beef system? and, secondly, how can the sheep system be organized to compete with a potentially highly efficient dairy beef system?

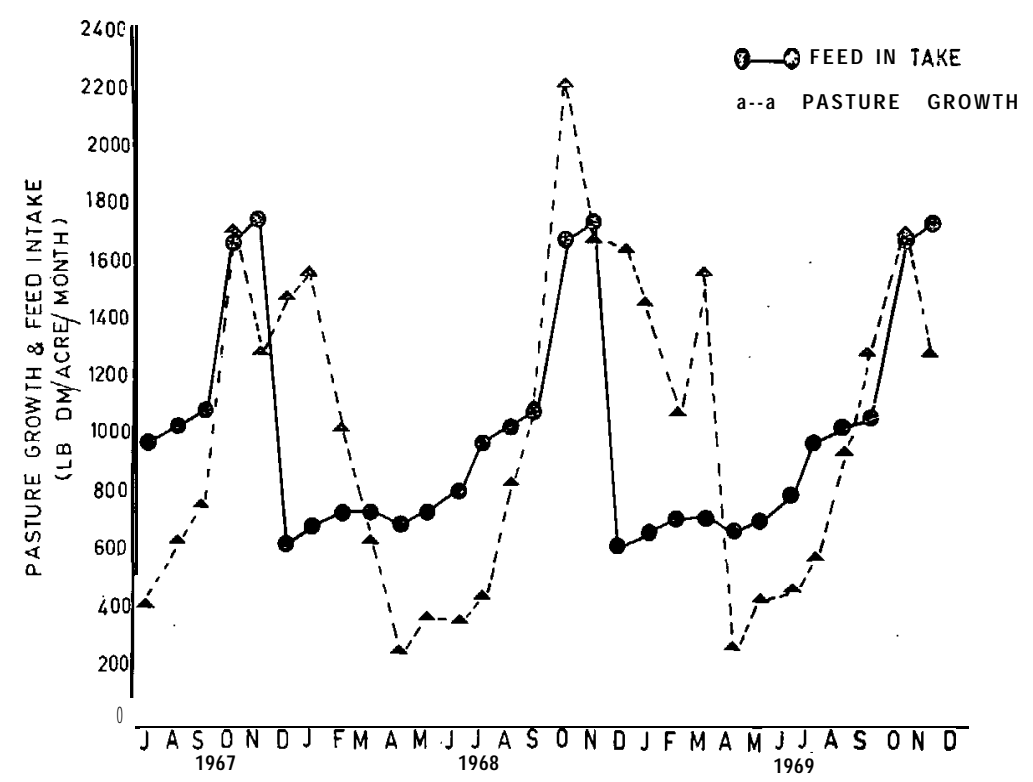

Fig. 3: Pasture growth and feed intake, 2.0 cattle per acre. 
TABLE 6: POTENTIAL ANNUAL PRODUCTION PER ACRE FROM DAIRY BEEF

(Assuming $170 \mathrm{lb}$ L.W. weaner being slaughtered at $850 \mathrm{lb}$ L.W.i.e., $374 \mathrm{lb}$ net carcass gain and pasture production of 13,000 lb DM/ acre)

\begin{tabular}{cccc}
\hline $\begin{array}{c}\text { Average } \\
\text { L.W. Gain } \\
(\text { lb day })\end{array}$ & $\begin{array}{c}\text { Feed } \\
\text { Requirement } \\
(\text { lb D M })\end{array}$ & $\begin{array}{c}\text { Stocking Rate } \\
\text { (animals/acre) }\end{array}$ & $\begin{array}{c}\text { Net Meat } \\
\text { Production } \\
\text { (lb/acre) }\end{array}$ \\
\hline 1 & 8,723 & 1.49 & 557 \\
$1 \frac{1}{2}$ & 6,460 & 2.01 & 752 \\
2 & 5,333 & 2.44 & 913 \\
$2 \frac{1}{2}$ & 4,656 & 2.79 & 1,043 \\
\hline
\end{tabular}

Shown in Table 6 are the potential productions per acre from dairy beef systems aimed at slaughtering at 850 $\mathrm{lb}$ liveweight for animals gaining at different rates of a pasture producing $13,000 \mathrm{lb} \mathrm{DM} /$ acre/annum. Net meat production per acre increases as the daily liveweight gain increases, since the ratio of production to maintenance value of the ration increases. It is probably unrealistic to envisage an animal gaining weight at a constant rate throughout its lifetime. Consequently, in Fig. 3, the feed requirements of an animal gaining at $1.5 \mathrm{lb}$ per day for 170 days plus 90 days during the, winter period at $1.0 \mathrm{lb}$ per day and 167 days at $2.0 \mathrm{lb}$ per day have been compared with the seasonal pasture growth measured on the dairy beef area at Ruakura over the last three years. Under this situation, which involves considerable conservation of feed as either hay, silage, or autumn-saved pasture in the December to March period, 2.18 animals per acre could be carried, producing $815 \mathrm{lb}$ of net carcass weight per acre/ year. This is probably close to the maximum production per acre possible without forage cropping or concentrate feeding.

To reduce proportionally the maintenance feed overhead cost of the ewe, one method is to make her produce more lamb meat. This can be done by three methods:

(1) Carry lamb on to heavier liveweights before slaughter. ing.

(2) Increase the number of ewes born per ewe at each lambing.

(3) Increase the frequency of lambing. 
Shown in Table 7 are the estimated feed requirements of ewes lambing either. singles or twins once yearly or three times every two years. Under these situations it is theoretically possible to produce over $500 \mathrm{lb}$ of lamb meat per acre. Neglecting the reproductive physiological problems which are to some extent being overcome, it is important to see how the feed requirements of ewes on these systems would fit the seasonal pattern of pasture growth. In Fig. 4 the feed requirements of 10 ewes per acre producing only single lambs once a year are compared with

TABLE 7: PRODUCTIVITY OF A ROMNEY BREEDING EWE ON PASTURE PRODUCING 13,000 lb DM/ACRE/YEAR

\begin{tabular}{|c|c|c|c|}
\hline $\begin{array}{l}\text { Annual Feed } \\
\text { Management and } \\
\text { Fertility }\end{array}$ & $\begin{array}{l}\text { Requirement } \\
\text { (lb DM/acre) }\end{array}$ & $\begin{array}{l}\text { No. Ewes } \\
\text { per acre }\end{array}$ & $\begin{array}{l}\text { Lamb Meat } \\
(l b / \text { acre })\end{array}$ \\
\hline \multicolumn{4}{|c|}{ Once yearly lambing: } \\
\hline $\begin{array}{l}\text { Single } \\
\text { Twins }\end{array}$ & $\begin{array}{l}1,230 \\
1,570\end{array}$ & $\begin{array}{r}10.6 \\
8.3\end{array}$ & $\begin{array}{l}318 \\
415\end{array}$ \\
\hline \multicolumn{4}{|c|}{$\begin{array}{l}\text { Three lambings every two } \\
\text { years: }\end{array}$} \\
\hline $\begin{array}{l}\text { Single } \\
\text { Twins }\end{array}$ & $\begin{array}{r}1,460 \\
1,860\end{array}$ & $\begin{array}{l}8.9 \\
7.0\end{array}$ & $\begin{array}{l}400 \\
525\end{array}$ \\
\hline
\end{tabular}

the measured pasture growth at Ruakura on a 10 ewes per acre treatment over the last three years. The fit between feed requirements and pasture growth is remarkably good with a slight surplus occurring during the late spring-early summer period and a moderate deficit in the winter period. When the same pasture growth curve is compared with the feed requirements of 10 ewes per acre lambing twins once a year, only a slightly greater winter feed deficit would occur but now a considerable spring-summer feed deficit occurs. To overcome this problem, either the stocking rate must be reduced from 10 ewes per acre to a calculated value

of eight ewes per acre, or methods of supplying additional supplementary feed during the summer and winter periods must be used. If the feed requirements of ewes producing single lambs three times every two years are considered, the feed situation becomes most confused. At the first lambing, feed requirements coincide with feed availability, but thereafter they are completely out of phase. Large winter and late summer-early autumn deficits occur at the next two lambings before feed requirements and feed availability match up again at the fourth lambing. Further- 
10 EWESIACRE - SINGLE LAMB $3 \times$ IN 2 YEARS
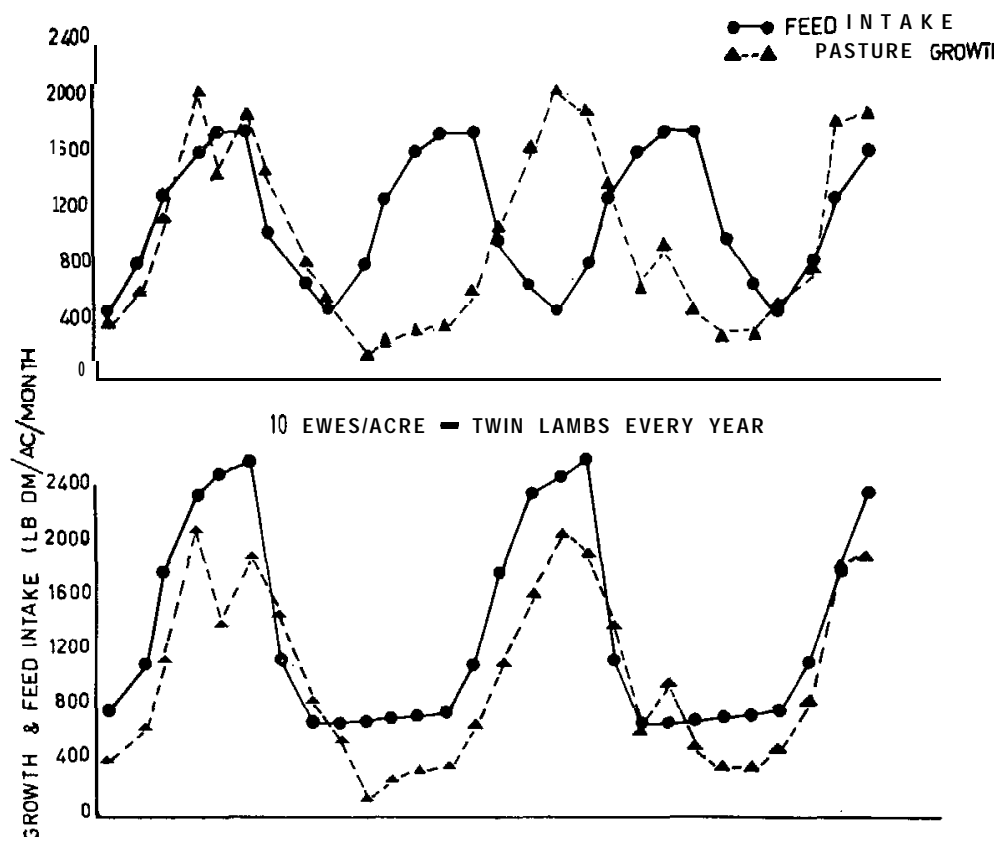

w 10 EWESIACRE - SINGLE LAMB EVERY YEAR

$\frac{5}{5}$

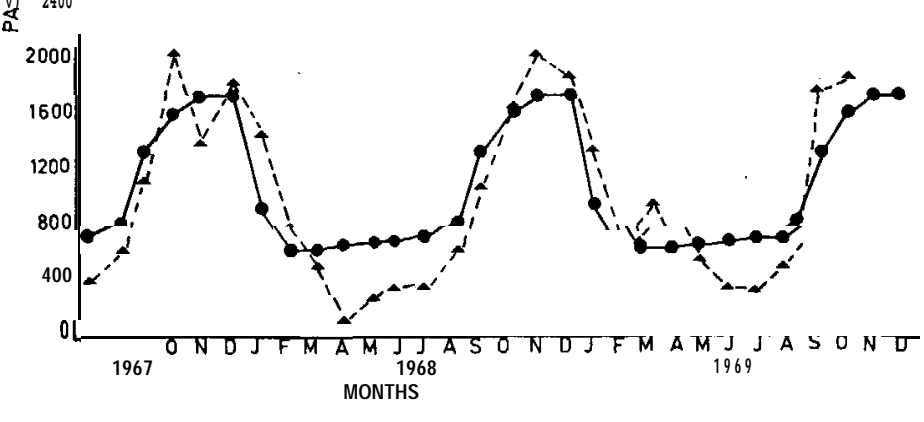

FIG. 4: Pasture growth and feed intake, 10 ewes per acre with different lambing rates.

more, a spring pasture growth period occurs when feed requirements are minimal. Under this situation, reducing stocking rates to eight to nine ewes per acre, so that yearly total feed requirements equal the amount of feed grown over the year, is of little benefit. In this situation, the surplus spring growth must be conserved until lambing 
occurs fourth months later and it must be in a form suitable for feeding to the lactating ewe. Suitable feed must also be conserved or specially grown for the feeding of winter lambing ewes.

To increase lamb meat production per acre to the levels possible under intensive young beef production, certain agronomic and nutritional problems must be solved. The most important of these appear to be:

(1) The provision of some form of supplementary feeding during summer to sustain lactation in the ewe.

(2) The provision of high quality winter rations again capable of meeting lactational requirements.

(3) The provision of feeds suitable to meet the nutritional requirements of young growing lambs weaned at ages anywhere between two and eight weeks of age.

By investigations into the uses of corn silage, nitrogenous fertilizers, special-purpose pastures and forage cropping, some of these problems may be overcome.

\section{REFERENCES}

Lynch, P. B., 1960: N.Z. Dept. Agric. Bull. 399: 74

Walker, D E. K., 1959: Proc. Ruakura Fmrs' Conf. Week: 41-9.

\section{DISCUSSION}

Stewart asked if interest and labour charges were taken into account when calculating gross margins. He also felt that capital inputs would vary considerably. Joyce replied no notice had been taken of the capital involved and that it would be impossible to calculate labour costs. He still considered the beef cattle system to be more profitable. Asked to comment on the high content of Yorkshire fog in pastures, Joyce stated that it was mostly in lowstocked areas. To a question from Cullen as to why the wether system was inferior to the ewe and lamb system, Joyce said that was probably because of understocking with the wethers. Large areas had been shut up for hay. He was now increasing the stocking rate in this system. Ayson asked if there was better utilzation with the ewes and lambs, to which Joyce replied that at 10 ewes per acre utilization was $90 \%$, and with cattle $85 \%$. Barnes (U.S.A.) suggested there might be an advantage in a combined sheep and cattle enterprise. Joyce agreed, saying that the combination would be studied if a trial could be arranged. However, unless rigid principles were set, it would be difficult to integrate sheep and cattle systems successfully. Browne (Ireland) commented that he had found that lambs performed better in the presence of cattle but he had not been 
able to sort out any stocking rate effect. To a questioner, Joyce explained -that his ewe-equivalent figure of six sheep for one cattle beast had been derived from the figure of $1,230 \mathrm{lb} \mathrm{DM}$ for a ewe and $7,320 \mathrm{lb} \mathrm{DM}$ for the beast. Jobiin commented that the thinking in gross margins might be more relevant to the traditional beef type weaners rather than to the dairy type. Stewart considered the variation would depend on the value of the cattle, while Candy thought that the relative value per $l b$ of the different meats would have to be taken into consideration. 